\title{
Response of Multistory Irregular L Shape Building under Basic Wind Speed of $39 \mathrm{~m} / \mathrm{s}$
}

\author{
Ashish Sadh ${ }^{\dagger}$, Sagar Jamle ${ }^{* *}$ and Ankit Pal ${ }^{\dagger}$ \\ †Department of Civil Engineering, Oriental University Indore, (M. P.), India. \\ Received 06 Sept 2018, Accepted 10 Nov 2018, Available online 12 Nov, Vol.8, No.6 (Nov/Dec 2018)
}

\begin{abstract}
Wind analysis in this era considered as a main criteria for modern tall buildings such that the tall buildings are considered as a cantilever structure which is fixed at its base and is free at other end. These multistory buildings are not same in plan and having different projections which is vulnerable to wind and its exposures. The main criteria in this research work is to present the position of these tall buildings having plan of $L$ - shape 20 story building under a basic wind speed of $39 \mathrm{~m} / \mathrm{s}$. Using Staad pro software, a total of 4 cases has analyzed. Dimension of plan is different from both the projection on which wind is applied in all four directions. A comparison of result parameters like displacements, story drift, axial forces in column, shear in beam in both longitudinal and transverse direction are made for all the models and suggestions are made to choose which position is the best of all.
\end{abstract}

Keywords: L shape building, Maximum displacement, Structural position, Staad pro, Story drift, Wind effects.

\section{Introduction}

In this era, futuristic structures are taken into account for modern lifestyles people and their way of living. For this, construction leads to improvements in the development of high rise building by the fact that there is scarcity of land. Due to this requirement, modern analysis and design procedures have taken into account to construct new light and slender structures. These are susceptible to larger wind and seismic effects. Now we are solely depending on the previous historical data and it will unable to find in future that which kind of load is going to fail the structure. For that it is necessary to analyze the structure for each horizontal loading. Consider the storm effects which has considered as higher effects as compared to normal wind loading.

IS: 875 (part-3)-1987, provides the standard method to find out the design pressures by wind loads along with different factors such as risk coefficient, topography factor, terrain roughness and height factor taken from IS 875 Part III from different clauses. The pressure obtained for any height will be directly applied to effective area of structure. Since code remains inaudible about how the structure will behave on the same computed load when the structure is rotated along its vertical axis with plan regularity as well as irregularity.

*Corresponding author Sagar Jamle (ORCID ID: 0000-0002-68906971) and Ankit Pal are working Assistant Professors; Ashish Sadh is a M.Tech Scholar

DOI: https://doi.org/10.14741/ijcet/v.8.6.7
Therefore, it is proposed to perform wind analysis longitudinally and transversely for different extruded plan extended to wide area such as irregular $\mathrm{L}$ shaped multistoried building. Hence the search will complete when the exact location is determined. Moreover search also extend when the applied wind strikes the structure and creates the effects to neighboring structures.

\section{Objective}

This study is solely based on the wind analysis and the parametric effects are determined by using different $\mathrm{L}$ shaped plan cases under wind speed of $39 \mathrm{~m} / \mathrm{s}$.

1. To determine similar and pairing patterns by analyzing $\mathrm{L}$ shape multistory building of Case A, Case B, Case C and Case D.

2. To find and check the reduction in all the parameters when structural projection part is more or less.

3. To analyze the structure graphically to obtain real values if no criterion of extra supports like bracings, shear wall etc. provided.

4. To obtain Maximum nodal displacements, story drift for all cases.

5. To obtain, compare and analyze axial forces in column at ground level, shear forces and moments in beam. 


\section{Methodology in Wind Analysis}

Method of analysis is solely depend on wind pressure in this work. The main criteria is to find the wind pressures at particular height above $10 \mathrm{~m}$ as per codal provisions of IS 875 part III and feed these values in Staad pro so that the software apply the manually calculated pressures of particular intensity to a particular nodal height.

Pressure of wind above ground level will be calculated as:

$P_{\mathrm{Z}}=0.6 \mathrm{~V}_{\mathrm{Z}}^{2}$

where

$\mathrm{V}_{\mathrm{z}}=$ design wind speed at any height $\mathrm{z}$ in $\mathrm{m} / \mathrm{s}$,

$\mathbf{V}_{\mathrm{z}}=\mathbf{k}_{\mathbf{1}} \mathbf{k}_{\mathbf{2}} \mathbf{k}_{\mathbf{3}} \mathbf{V}_{\mathrm{b}}$

Risk coefficients for different classes of structures in different wind speed zones taken from IS 875 Part III clause 5.3.1

$\mathrm{k} 1$ = probability factor (risk coefficient) (clause 5.3.1 IS 875 Part III),

$\mathrm{k}_{1}=\frac{\mathrm{X}_{\mathrm{N}, \mathrm{P}} \mathrm{N}}{\mathrm{X}_{50,0.63}}=\frac{\mathrm{A}-\mathrm{B}\left[\ln \left\{-\frac{1}{\mathrm{~N}} \ln \left(1-\mathrm{P}_{\mathrm{N}}\right)\right\}\right]}{\mathrm{A}+4 \mathrm{~B}}$

Where,

$\mathrm{N}=$ mean probable design life of the structure in years. $\mathrm{P}_{\mathrm{N}}=$ risk level in $\mathrm{N}$ consecutive years (probability that the design wind speed is exceeded at least once in $\mathrm{N}$ successive years), nominal value $=0.63$.

$\mathrm{X}_{\mathrm{N}, \mathrm{P}}=$ extreme wind speed for given value of $\mathrm{N}$ and $\mathrm{P}_{\mathrm{N}}$; and

$\mathrm{X}_{50,0.63}=$ extreme wind speed for $\mathrm{N}=50$ years and $\mathrm{P}_{\mathrm{N}}=$ 0.63

A and B are coefficients having the following values for different basic wind speed zones:

Table 1 Values for different basic wind speed zones

\begin{tabular}{|c|c|c|}
\hline Zone & A & B \\
\hline $33 \mathrm{~m} / \mathrm{s}$ & 83.2 & 9.2 \\
\hline $39 \mathrm{~m} / \mathrm{s}$ & 84.0 & 14 \\
\hline $44 \mathrm{~m} / \mathrm{s}$ & 88.0 & 18 \\
\hline $47 \mathrm{~m} / \mathrm{s}$ & 88.0 & 20.5 \\
\hline $50 \mathrm{~m} / \mathrm{s}$ & 88.8 & 22.8 \\
\hline $55 \mathrm{~m} / \mathrm{s}$ & 90.8 & 27.3 \\
\hline
\end{tabular}

$\mathrm{k}_{2}=$ terrain roughness and height factor taken from IS 875 Part III clause 5.3.2

$\mathrm{k}_{3}=$ topography factor taken from IS 875 Part III clause 5.3.3
$\mathrm{V}_{\mathrm{b}}=$ basic wind speed of any particular region taken from IS 875 Part III Appendix A.

\section{Structure Modeling}

The complete framed structure has been designed in Staad pro, analysis and design tool. The L shape multistory model descriptions according to its geometry, properties, loading, material and support are listed in Table 2. Details of dead and live loading are listed in Table 3. Wind loading which is applied for $\mathrm{L}$ shape plan of various cases model is shown in Table 4. Details of loading combinations as per I.S recommendations are listed in Table 5 respectively. Figure 1 to 4 shows various detailed L shaped plans and 3D view is shown in Figure 5. Table 6 shows the details of $\mathrm{L}$ shape multistory building cases that are taken into account in this research work.

Table 2 Description of L-shape building

\begin{tabular}{|c|c|}
\hline Building configuration & $\mathrm{G}+19$ (commercial) \\
\hline Plan of building & $\begin{array}{c}\text { Irregular - L shaped } \\
\text { (CASE A, B, C, D) }\end{array}$ \\
\hline Plinth area & $700 \mathrm{~m}^{2}$ \\
\hline $\begin{array}{c}\text { Height of building above } \\
\text { ground level }\end{array}$ & $70 \mathrm{~m}$ \\
\hline Floor height & $3.5 \mathrm{~m}$ \\
\hline Depth of footing & $50 \mathrm{~m} \mathrm{x} 30 \mathrm{~m}$ \\
\hline Dimensions of building & $5 \mathrm{~m}$ \\
\hline Each bay in X and Z direction & $300 \mathrm{~mm} \times 450 \mathrm{~mm}$ \\
\hline Size of beam & $350 \mathrm{~mm} \mathrm{x} \mathrm{500} \mathrm{mm}$ \\
\hline Size of column & $150 \mathrm{~mm}$ \\
\hline Slab Thickness & M25 \& Fe 415 grade \\
\hline Concrete and Steel Grade & Fixed \\
\hline Support &
\end{tabular}

Table 3 Details of Dead and Live loading

\begin{tabular}{|c|c|}
\hline Floor Finish load & $3 \mathrm{KN} / \mathrm{m}^{2}$ \\
\hline Wall load (External) & $13.65 \mathrm{KN} / \mathrm{m}$ \\
\hline Wall load (Internal) & $7.66 \mathrm{KN} / \mathrm{m}$ \\
\hline Wall load (Roof Parapet) & $7.66 \mathrm{KN} / \mathrm{m}$ \\
\hline $\begin{array}{c}\text { Water proofing (including } \\
\text { terrace finish) }\end{array}$ & $3.2 \mathrm{KN} / \mathrm{m}^{2}$ \\
\hline Live load for floor and roof & $5 \mathrm{KN} / \mathrm{m}^{2} \& 2 \mathrm{KN} / \mathrm{m}^{2}$ \\
\hline
\end{tabular}

Table 4 Details of Wind loading

\begin{tabular}{|c|c|}
\hline Basic wind speed & $39 \mathrm{~m} / \mathrm{s}$ \\
\hline Exposure & $85 \%$ \\
\hline $\begin{array}{c}\text { Wind load in }+\mathrm{X} \\
\text { direction }\end{array}$ & $\begin{array}{c}\text { As per intensity along height in }+\mathrm{X} \\
\text { direction }\end{array}$ \\
\hline $\begin{array}{c}\text { Wind load in }-\mathrm{X} \\
\text { direction }\end{array}$ & $\begin{array}{c}\text { As per intensity along height in }-\mathrm{X} \\
\text { direction }\end{array}$ \\
\hline $\begin{array}{c}\text { Wind load in }+\mathrm{Z} \\
\text { direction }\end{array}$ & $\begin{array}{c}\text { As per intensity along height in }+\mathrm{Z} \\
\text { direction }\end{array}$ \\
\hline $\begin{array}{c}\text { Wind load in }-\mathrm{Z} \\
\text { direction }\end{array}$ & $\begin{array}{c}\text { As per intensity along height in }-\mathrm{Z} \\
\text { direction }\end{array}$ \\
\hline
\end{tabular}


Table 5 Details of loading combinations as per IS recommendations

\begin{tabular}{|c|c|}
\hline S. No. & Load Combinations \\
\hline 1 & 1.5 (DL+LL) \\
\hline 2 & $1.5(\mathrm{DL}+\mathrm{WLX})$ \\
\hline 3 & $1.5(\mathrm{DL}-\mathrm{WLX})$ \\
\hline 4 & $1.5(\mathrm{DL}+\mathrm{WLZ})$ \\
\hline 5 & $1.5(\mathrm{DL}-\mathrm{WLZ})$ \\
\hline 6 & $1.2(\mathrm{DL}+\mathrm{LL}+\mathrm{WLX})$ \\
\hline 7 & $1.2(\mathrm{DL}+\mathrm{LL}-\mathrm{WLX})$ \\
\hline 8 & $1.2(\mathrm{DL}+\mathrm{LL}+\mathrm{WLZ})$ \\
\hline 9 & $1.2(\mathrm{DL}+\mathrm{LL}-\mathrm{WLZ})$ \\
\hline 10 & 0.9 DL+1.5WLX) \\
\hline 11 & 0.9 DL-1.5WLX) \\
\hline 12 & 0.9 DL+1.5WLZ) \\
\hline 13 & 0.9 DL-1.5WLZ) \\
\hline
\end{tabular}

Table 6 Details of L shape multistory building cases

\begin{tabular}{|c|c|}
\hline CASE A & $\begin{array}{l}30 \mathrm{~m} \text { in }+\mathrm{X} \text { direction with } 50 \mathrm{~m} \text { in }-\mathrm{Z} \\
\text { direction }\end{array}$ \\
\hline CASE B & $\begin{array}{l}30 \mathrm{~m} \text { in }-\mathrm{X} \text { direction with } 50 \mathrm{~m} \text { in }-\mathrm{Z} \\
\text { direction }\end{array}$ \\
\hline CASE C & $\begin{array}{c}30 \mathrm{~m} \text { in }+\mathrm{X} \text { direction with } 50 \mathrm{~m} \text { in }+\mathrm{Z} \\
\text { direction }\end{array}$ \\
\hline CASE D & $\begin{array}{l}30 \mathrm{~m} \text { in }-\mathrm{X} \text { direction with } 50 \mathrm{~m} \text { in }+\mathrm{Z} \\
\text { direction }\end{array}$ \\
\hline
\end{tabular}

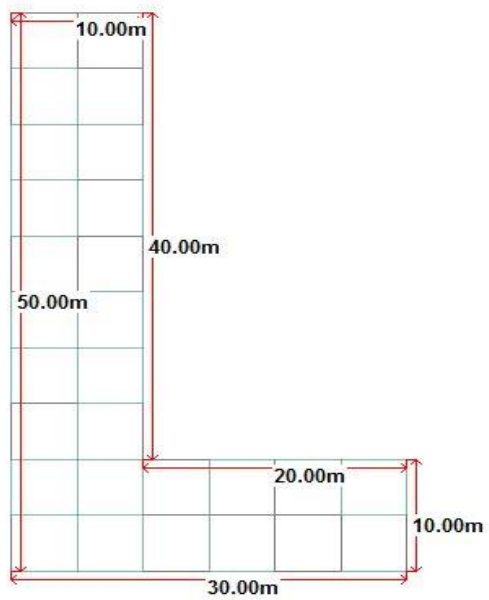

Fig.1 L shape building CASE A

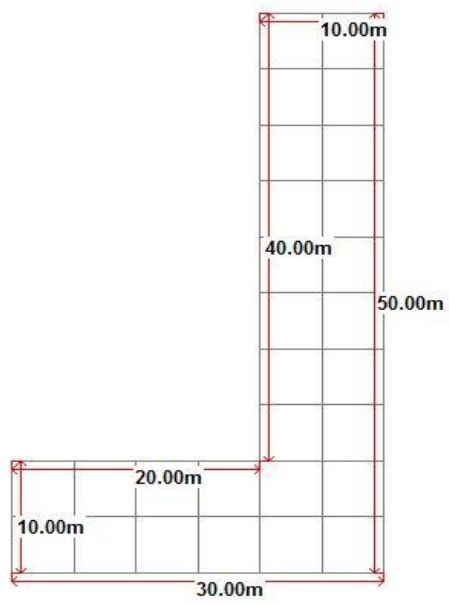

Fig. 2 L shape building CASE B

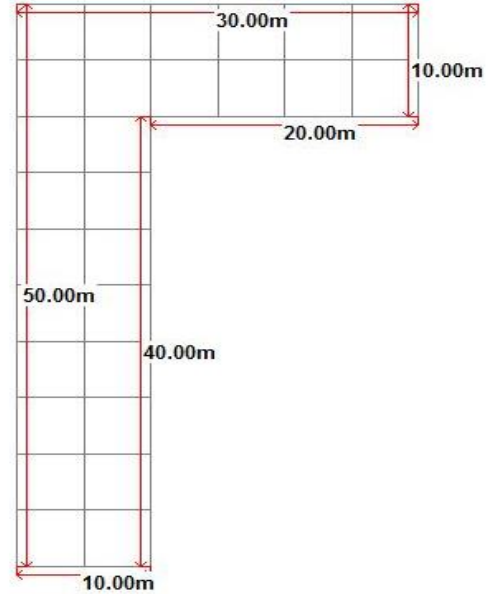

Fig. 3 L shape building CASE C

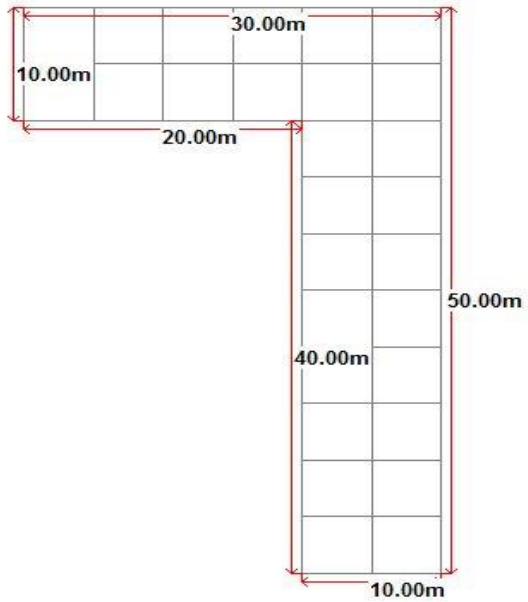

Fig. 4 L shape building CASE D

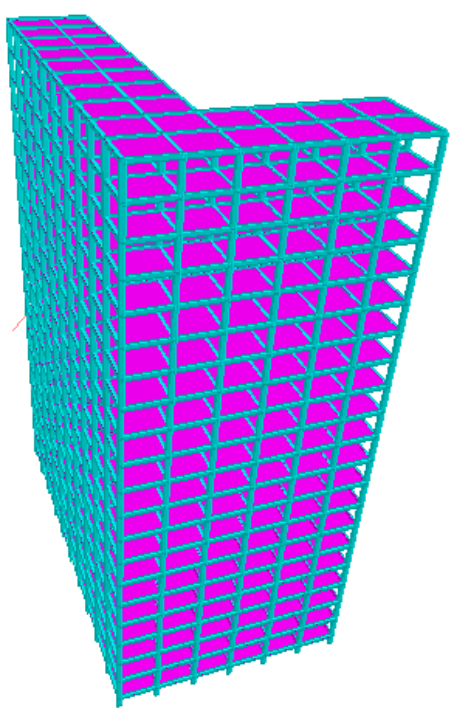

Fig. 5 3D view of L shape Multi-story building

\section{Results and Discussions}

After the applications of wind pressure along the height of L shape multistory building, analytic results 
for medium soil condition for different cases due to wind effects at a speed of $39 \mathrm{~m} / \mathrm{s}$ are as follows:-

Table 7 Maximum nodal displacement in $\mathrm{X}, \mathrm{Y}$ and $\mathrm{Z}$ direction for all 4 cases under wind speed of $39 \mathrm{~m} / \mathrm{s}$

\begin{tabular}{|c|c|c|c|}
\hline \multirow{2}{*}{$\begin{array}{c}\text { L SHAPED } \\
\text { BUILDING } \\
\text { CASES }\end{array}$} & \multicolumn{3}{|c|}{ Maximum Displacement } \\
\cline { 2 - 4 } & $\begin{array}{c}\text { X direction } \\
\text { (mm) }\end{array}$ & $\begin{array}{c}\text { Y direction } \\
\text { (mm) }\end{array}$ & $\begin{array}{c}\text { Z direction } \\
\text { (mm) }\end{array}$ \\
\hline CASE A & 326.896 & 104.491 & 176.305 \\
\hline CASE B & 326.896 & 104.491 & 176.305 \\
\hline CASE C & 325.373 & 104.491 & 198.524 \\
\hline CASE D & 325.373 & 104.491 & 198.524 \\
\hline
\end{tabular}

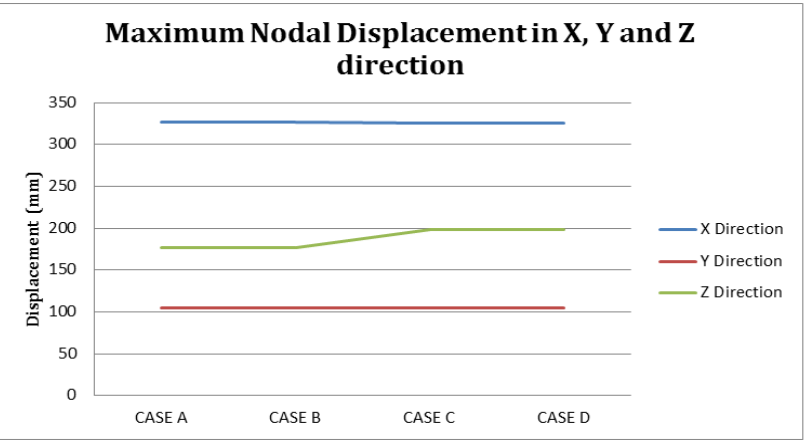

Graph 1 Graphical representation of maximum nodal displacement in $\mathrm{X}, \mathrm{Y}$ and $\mathrm{Z}$ direction for all 4 Cases under wind speed of $39 \mathrm{~m} / \mathrm{s}$.

Table 8 Story drift in X direction for all 4 Cases under wind speed of $39 \mathrm{~m} / \mathrm{s}$

\begin{tabular}{|c|c|c|c|c|}
\hline \multirow{2}{*}{ Height (m) } & \multicolumn{4}{|c|}{ Story Drift } \\
\cline { 2 - 5 } & \multicolumn{4}{|c|}{ For X Direction (cm) } \\
\cline { 2 - 5 } & CASE A & CASE B & CASE C & CASE D \\
\hline 0 & 0 & 0 & 0 & 0 \\
\hline 3.5 & 1.0821 & 1.0754 & 1.1179 & 1.0754 \\
\hline 7 & 1.2626 & 1.2491 & 1.3035 & 1.2491 \\
\hline 10.5 & 1.2791 & 1.2591 & 1.3198 & 1.2591 \\
\hline 14 & 1.271 & 1.2448 & 1.3108 & 1.2448 \\
\hline 17.5 & 1.253 & 1.2209 & 1.2917 & 1.2209 \\
\hline 21 & 1.2278 & 1.1900 & 1.2651 & 1.1900 \\
\hline 24.5 & 1.1962 & 1.1530 & 1.2320 & 1.1530 \\
\hline 28 & 1.1587 & 1.1105 & 1.1929 & 1.1105 \\
\hline 31.5 & 1.116 & 1.0631 & 1.1484 & 1.0631 \\
\hline 35 & 1.0686 & 1.0114 & 1.0991 & 1.0114 \\
\hline 38.5 & 1.017 & 0.9558 & 1.0456 & 0.9558 \\
\hline 42 & 0.9614 & 0.8966 & 0.9879 & 0.8966 \\
\hline 45.5 & 0.9021 & 0.8340 & 0.9263 & 0.8340 \\
\hline 49 & 0.8393 & 0.7684 & 0.8613 & 0.7684 \\
\hline 52.5 & 0.7735 & 0.7001 & 0.7932 & 0.7001 \\
\hline 56 & 0.7053 & 0.6299 & 0.7226 & 0.6299 \\
\hline 59.5 & 0.6351 & 0.5580 & 0.6500 & 0.5580 \\
\hline 63 & 0.5632 & 0.4849 & 0.5757 & 0.4849 \\
\hline 66.5 & 0.4908 & 0.4117 & 0.5008 & 0.4117 \\
\hline 70 & 0.4259 & 0.3461 & 0.4337 & 0.3461 \\
\hline & & & 15611 & \\
\hline
\end{tabular}

Table 9 Story drift in $\mathrm{Z}$ direction for all 4 Cases under wind speed of $39 \mathrm{~m} / \mathrm{s}$

\begin{tabular}{|c|c|c|c|c|}
\hline \multirow{2}{*}{$\begin{array}{c}\text { Height } \\
(\mathrm{m})\end{array}$} & \multicolumn{4}{|c|}{ Story Drift } \\
\cline { 2 - 5 } & \multicolumn{4}{|c|}{ For Z Direction (cm) } \\
\cline { 2 - 5 } & CASE A & CASE B & CASE C & CASE D \\
\hline 0 & 0 & 0 & 0 & 0 \\
\hline 3.5 & 0.8995 & 0.8995 & 0.9861 & 0.9861 \\
\hline 7 & 0.9673 & 0.9673 & 1.0549 & 1.0549 \\
\hline 10.5 & 0.9501 & 0.9501 & 1.0302 & 1.0302 \\
\hline 14 & 0.9252 & 0.9252 & 0.9972 & 0.9972 \\
\hline 17.5 & 0.8958 & 0.8958 & 0.9595 & 0.9595 \\
\hline 21 & 0.8625 & 0.8625 & 0.9178 & 0.9178 \\
\hline 24.5 & 0.8259 & 0.8259 & 0.8727 & 0.8727 \\
\hline 28 & 0.7863 & 0.7863 & 0.8246 & 0.8246 \\
\hline 31.5 & 0.744 & 0.744 & 0.7738 & 0.7738 \\
\hline 35 & 0.6993 & 0.6993 & 0.7207 & 0.7207 \\
\hline 38.5 & 0.6527 & 0.6527 & 0.6658 & 0.6658 \\
\hline 42 & 0.604 & 0.604 & 0.6089 & 0.6089 \\
\hline 45.5 & 0.5533 & 0.5533 & 0.5501 & 0.5501 \\
\hline 49 & 0.5009 & 0.5009 & 0.4898 & 0.4898 \\
\hline 52.5 & 0.4468 & 0.4468 & 0.4280 & 0.4280 \\
\hline 56 & 0.3916 & 0.3916 & 0.3652 & 0.3652 \\
\hline 59.5 & 0.3353 & 0.3353 & 0.3016 & 0.3016 \\
\hline 63 & 0.278 & 0.278 & 0.2374 & 0.2374 \\
\hline 66.5 & 0.2199 & 0.2199 & 0.1728 & 0.1728 \\
\hline 70 & 0.1663 & 0.1663 & 0.1133 & 0.1133 \\
\hline
\end{tabular}

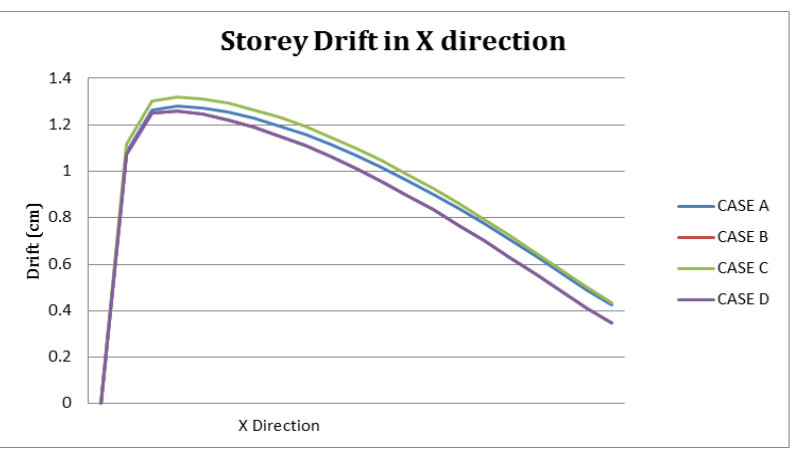

Graph 2 Graphical representation of story drift in X direction for all 4 Cases under wind speed of $39 \mathrm{~m} / \mathrm{s}$

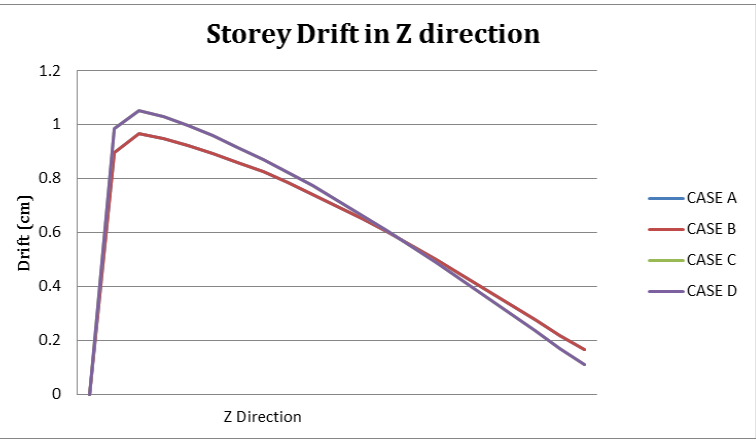

Graph 3 Graphical representation of story drift in Z direction for all 4 Cases under wind speed of $39 \mathrm{~m} / \mathrm{s}$ 
Table 10 Maximum axial forces in column at ground level for all 4 cases under wind speed of $39 \mathrm{~m} / \mathrm{s}$

\begin{tabular}{|c|c|}
\hline $\begin{array}{c}\text { L SHAPED BUILDING } \\
\text { CASES }\end{array}$ & $\begin{array}{c}\text { Maximum Axial Forces in } \\
\text { Column (KN) }\end{array}$ \\
\hline CASE A & 11464.173 \\
\hline CASE B & 11464.173 \\
\hline CASE C & 11464.174 \\
\hline CASE D & 11464.174 \\
\hline
\end{tabular}

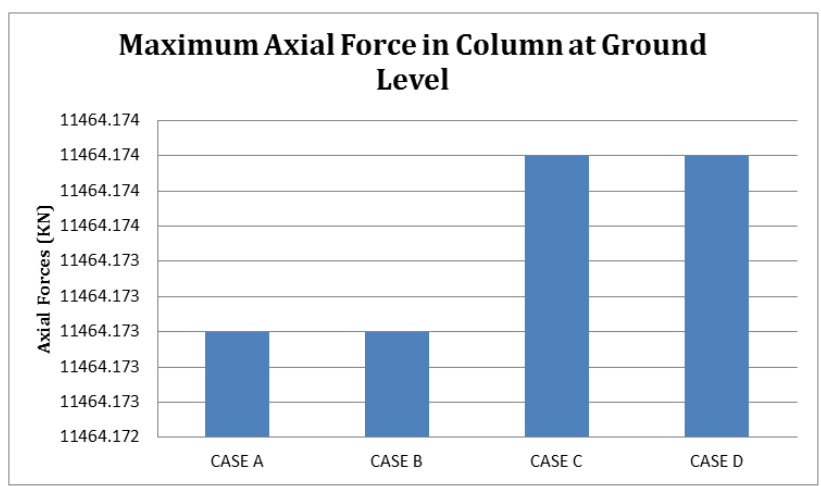

Graph 4 Graphical representation of maximum axial forces in column at ground level for all 4 cases under wind speed of $39 \mathrm{~m} / \mathrm{s}$

Table 11 Maximum shear forces in beam in X \& $\mathrm{Z}$ direction for all 4 cases under wind speed of $39 \mathrm{~m} / \mathrm{s}$

\begin{tabular}{|c|c|c|c|c|}
\hline \multirow{2}{*}{$\begin{array}{c}\text { L SHAPED } \\
\text { BUILDING } \\
\text { CASES }\end{array}$} & \multicolumn{4}{|c|}{ Maximum Shear Forces in Beam } \\
\cline { 2 - 5 } & $\mathrm{SY}$ & $\mathrm{SZ}$ & $\mathrm{SY}$ & $\mathrm{SZ}$ \\
\cline { 2 - 5 } & 166.911 & 0.302 & 154.088 & 0.424 \\
\hline CASE A & 166.911 & 0.302 & 154.088 & 0.424 \\
\hline CASE B & 166.806 & 0.320 & 154.088 & 0.424 \\
\hline CASE C & 166.806 & 0.320 & 154.088 & 0.424 \\
\hline CASE D & & & & \\
\hline
\end{tabular}

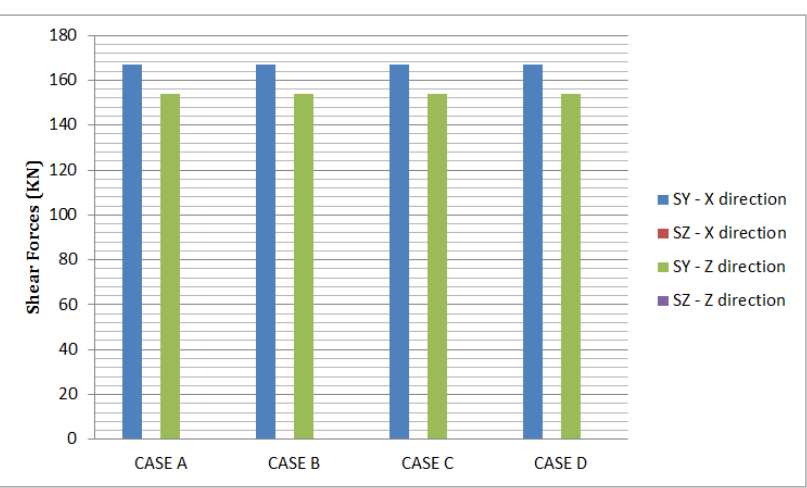

Graph 5 Graphical representation of maximum shear forces in beam in $\mathrm{X}$ and $\mathrm{Z}$ direction for all 4 cases under wind speed of $39 \mathrm{~m} / \mathrm{s}$.
Table 12 Maximum bending moment in beam in $\mathrm{X} \& \mathrm{Z}$ direction for all 4 cases under wind speed of $39 \mathrm{~m} / \mathrm{s}$

\begin{tabular}{|c|c|c|c|c|}
\hline \multirow{2}{*}{$\begin{array}{c}\text { L SHAPED } \\
\text { BUILDING } \\
\text { CASES }\end{array}$} & \multicolumn{3}{|c|}{ Maximum Bending Moment in Beam } \\
\cline { 2 - 5 } & $\mathrm{MY}$ & $\mathrm{MZ}$ & $\mathrm{MY}$ & $\mathrm{MZ}$ \\
\cline { 2 - 5 } & & 297.378 & 1.114 & 201.180 \\
\hline CASE A & 0.805 & 297.378 & 1.114 & 201.180 \\
\hline CASE B & 0.805 & 296.988 & 1.114 & 201.180 \\
\hline CASE C & 0.871 & 29601 & \multicolumn{2}{|c|}{ Z direction (KNm) } \\
\hline CASE D & 0.871 & 296.988 & 1.114 & 201.180 \\
\hline
\end{tabular}

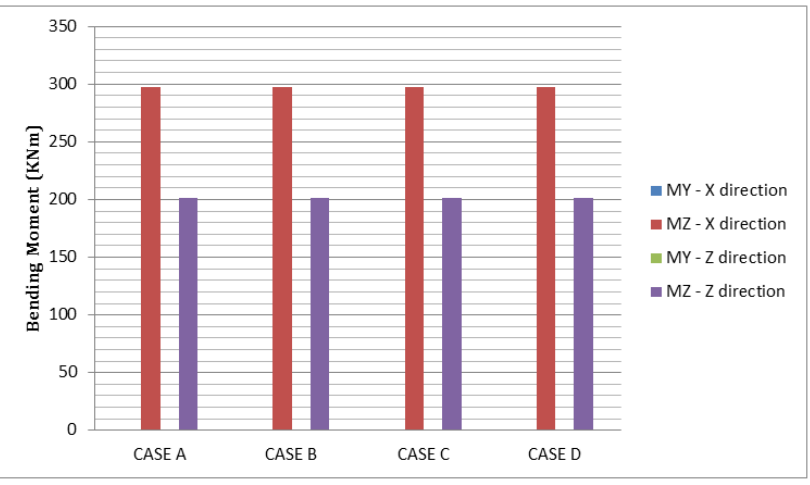

Graph 6 Graphical representation of maximum moments in beam in $\mathrm{X}$ and $\mathrm{Z}$ direction for all 4 cases under wind speed of $39 \mathrm{~m} / \mathrm{s}$.

\section{Conclusions}

It has been concluded from the above study that wind forces effects are less in $39 \mathrm{~m} / \mathrm{s}$ wind speed but during detailed analysis, all considered cases shows different values in all parameters.

1. Case A and Case B in almost all parameters show a same value pattern since these two cases are identical and make a pair. Same values are shown in Case C and Case D. It has also been concluded that when structural projection part is more, then there will definitely be a reduction in all the parameters.

2. Parametric results obtained show the real values, since there is no criterion of extra supports like bracings, shear wall etc. required.

3. Maximum nodal displacements has seen maximum in $\mathrm{X}$ direction for all cases. This is due to stiffness along $\mathrm{X}$ direction is less because wind projecting acting area is more.

4. Story drift seems to be maximum at $10.5 \mathrm{~m}$ for $\mathrm{X}$ direction and $7 \mathrm{~m}$ for $\mathrm{Z}$ direction. From this maximum values, due to wind effects, the drift values are again lowering down.

5. Axial forces seems to be same for all cases, shear forces and bending in $\mathrm{X}$ direction beams shows different values between identical pairs. No change in maximum shear forces and bending in beam in $\mathrm{Z}$ direction. 


\section{References}

Abhay Guleria, (2014), Structural Analysis of a Multi-story building using ETABS for Different plan configuration, International Journal of Engineering Research and Technology, ISSN: 0974-3154, Vol. 3, Issue 5, pp. 14811485.

Bhumika Pashine, V. D. Vaidya, Dr. D. P. Singh, (2016), Wind analysis of multistoried structure with $\mathrm{T}$ shape and $\mathrm{L}$ Shape geometry, International journal of Engineering Development and Research, ISSN: 2321-9939, Vol. 4, Issue 3, pp. 70-77.

D.R. Panchal and P.M. Marathe, (2011), Comparative Study of RCC, steel and composite ( $\mathrm{G}+30$ story) building, Institute of Technology, Nirma University, Ahmadabad, pp 01-06.

Hossein Moravej, Mahdi Hatami, Reza Naghshbandi, Yaser Mousavi Siamakani, (2015), Wind load analysis of buildings in hill-shape zone, International Journal of Applied Sciences and Engineering Research, ISSN: 22779442, Vol. 4, Issue 1, pp. 94-101.

IS 456: 2000, Plain and Reinforced Concrete - Code of Practice, Fourth revision, Bureau of Indian Standards, New Delhi, India.

IS: 875(Part 1)-1987, Code of Practice for Design loads (other than Earthquake) for Buildings and Structures, Part 1 Dead Loads - Unit Weights of Building Materials and Stored Materials, Second revision, Bureau of Indian Standards, New Delhi, India.

IS: 875(Part 2)-1987, Code of Practice for Design loads (other than Earthquake) for Buildings and Structures, Part 2 Imposed Loads, Second revision, Bureau of Indian Standards, New Delhi, India.

IS: 875(Part 3)-1987, Code of Practice for Design loads (other than Earthquake) for Buildings and Structures, Second revision, Bureau of Indian Standards, New Delhi, India.

J. A. Amin, A. K. Ahuja, (2008), Experimental Study of Wind Pressures on Irregular-Plan Shape Buildings. BBAA VI International Colloquium on: Bluff Bodies Aerodynamics \& Applications Milano, Italy, pp. 1-9.
Jawad Ahmed, H S Vidyadhar, (2013), Wind Analysis and Design of Multi Bay Multi Story 3D RC Frame, International Journal of Engineering Research \& Technology (IJERT), ISSN: 2278-0181 Vol. 2, Issue 9, pp. 2567-2570.

Mahesh Suresh Kumawat, L. G. Kalurkar, (2014), Analysis and Design of Multistory Building Using Composite Structure, International Journal of Structural and Civil Engineering Research, ISSN: 2319-6009, Vol. 3, Issue 2, pp. 125-137.

Md. Rashedul Kabir, Debasish Sen, Md. Mashfiqul Islam, (2015), Response of multi-story regular and irregular buildings of identical weight under static and dynamic loading in context of Bangladesh, International Journal of Civil and Structural Engineering, ISSN: 0976 - 4399, Vol. 5, Issue 3, pp. 252-260.

Ming Gu, (2009), Study on Wind Loads and Responses of Tall Buildings and Structures, The Seventh Asia-Pacific Conference on Wind Engineering, APCWE-VII, pp. 1-21.

Ravinder Ahlawat and Ashok K. Ahuja, (2015), Wind loads on ' $T$ ' Plan Shape Tall Buildings, Journal of Academia and Industrial Research (JAIR), ISSN: 2278-5213, Vol. 4, Issue 1, pp. 27-30.

Ravinder Ahlawat and Ashok K. Ahuja, (2015), Wind loads on ' $\mathrm{Y}$ ' plan shape tall building, International Journal of Engineering and Applied Sciences (IJEAS), ISSN: 2394-3661, Vol. 2, Issue 4, pp. 80-83.

Sanhik Kar Majumder, Priyabrata Guha, (2014), Comparison Between Wind And Seismic Load On Different Types Of Structures, International Journal Of Engineering Science Invention, ISSN: 2319-6734, Vol. 3, Issue 4, 2014, pp. 42-54. Syed Fahad Ali, S.A. Bhalchandra, (2015), Study on Seismic Analysis of RCC and Steel-Concrete Composite Structure and Cost Comparison with Different Support Conditions, International Journal for Scientific Research \& Development ISSN: 2321-0613, Vol. 3, Issue 9, pp. 354-359. 